Darija Skubic

Mateja Dagarin Fojkar

University of Ljubljana, Slovenia
2017, Vol. 14 (2), 103-116(122) revije.ff.uni-lj.si/elope

doi: 10.4312/elope.14.2.103-116

UDC: 81'243:37.091.3(497.4)

\title{
Pre-Service Teachers' Beliefs about Foreign Language Learning: A Study of Three Different Teacher Training Study Programmes in Slovenia
}

\author{
ABSTRACT
}

It has been determined that beliefs about language learning are significant for the learning and teaching process, and that learners may differ in their beliefs towards learning a new language. Similarly, student-teachers of different subjects may differ in their beliefs about language learning. The main aim of this study was thus to investigate pre-service preschool teachers', primary school teachers', and special education teachers' beliefs about foreign language learning in Slovenia. Three different areas were researched more closely: beliefs about foreign language aptitude, beliefs about the nature of learning and beliefs about foreign language motivations and expectations. The BALLI questionnaire was used to gather data, with responses provided by170 first-year students. The results show that despite attending different teacher training study programmes, students do not differ significantly in their beliefs about language learning; however, in comparison to other studies, the results imply that learners from different cultures see language learning differently.

Keywords: language-learning beliefs; pre-service teacher training; primary school teachers; preschool teachers; special education teachers

\section{Prepričanja bodočih učiteljev o učenju tujih jezikov: študija treh različnih študijskih programov za izobraževanje učiteljev v Sloveniji}

\author{
POVZETEK
}

Ugotovljeno je bilo, da so prepričanja o učenju jezikov odločilnega pomena za učenje in poučevanje in da se učenci lahko razlikujejo v svojih prepričanjih o učenju novega jezika. Podobno se lahko študenti z različnih pedagoških študijskih programov razlikujejo v svojih prepričanjih o učenju jezikov. Glavni cilj te študije je bil raziskati prepričanja študentov predšolske vzgoje, razrednega pouka in specialno rehabilitacijske pedagogike o učenju tujih jezikov v Sloveniji. Tri področja so bila natančneje raziskana, to so: prepričanja študentov o tujejezikovni učljivosti, naravi učenja ter motivacijah za učenje tujega jezika in pričakovanjih, ki iz tega izhajajo. V študiji je bil uporabljen vprašalnik BALLI. V raziskavi je sodelovalo 170 študentov prvega letnika. Rezultati kažejo, da se kljub obiskovanju različnih študijskih programov prepričanja študentov o učenju tujih jezikov statistično pomembno ne razlikujejo; a v primerjavi z drugimi študijami nakazujejo, da učeči se iz različnih kultur različno zaznavajo učenje tujih jezikov.

Ključne besede: prepričanja o učenju (tujih) jezikov; izobraževanje prihodnjih učiteljev; (prihodnji) vzgojitelji; učitelji razrednega pouka; specialno rehabilitacijski pedagogi 


\section{Pre-Service Teachers' Beliefs about Foreign Language Learning: A Study of Three Different Teacher Training Study Programmes in Slovenia}

\section{Introduction}

Learner characteristics or individual characteristics, such as intelligence, language aptitude, motivation, and so on, play a significant role in language learning (Dörnyei 2003). Richardson $(1996,103)$ defined beliefs as "psychologically held understandings, premises, or propositions about the world that are felt to be true." Wesely (2012) argued that this definition covers a wide range of beliefs, including those about the target community, language, and culture, in addition to those about the learning situation. Gardner's work on motivation (1985) and his development of the Attitude/Motivation Test Battery (AMTB) has widely influenced the research on learner attitudes and beliefs about foreign language (henceforth: FL) learning. Wesely (2012) showed that beliefs about yourself as a learner, and attitudes to the language-learning process and speakers of a target language, affect the success of foreign language learning. Similarly, Cochran, McCallum, and Bell (2010) confirmed that attitudes about foreign language learning influence learning success, since positive attitudes increase foreign language exposure and the likelihood of engaging with opportunities to upgrade one's knowledge, while negative attitudes can hinder learning achievements.

Horwitz (1988) was amongst the pioneering researchers to investigate learner beliefs in more detail; she developed a detailed research instrument called BALLI (Beliefs About LanguageLearning Inventory), which assesses learner beliefs in five major areas, i.e., learner beliefs about foreign language aptitude, the difficulty of language learning, the nature of language learning, learning and communication strategies, and motivation and expectations.

The BALLI instrument has received some criticism, especially regarding its validity, because it was designed by language teachers and not learners themselves, as well as because of its division into different areas (Kuntz 1996); however, many researchers have evaluated this tool (among them Truitt 1995; Peacock 2001; Nikitina and Furuoka 2006), and concluded that it is suitable for assessing learner beliefs.

The instrument has been used in research studies in different countries, and the results of such works show that learner beliefs are context-specific. For example, Yavuz (2015), who explored the beliefs of Turkish students of English, determined that there is still a significant number of students who think the grammar translation method is the most appropriate one for teaching languages, and that the use of the students' mother tongue is most appropriate in early foreign language teaching. Sadeghi and Abdi (2015) collected data using the BALLI questionnaire and determined that Iranian intermediate and upper-intermediate students might have some beliefs that negatively affect their language learning (e.g., thinking that they should not be allowed to make mistakes at the beginning stages of learning). As stated by Richards and Lockhart (1994), beliefs can influence language learners' motivation to learn, their expectations about learning and the strategies they choose when learning, but they are also important for future language teachers, because their beliefs have a significant impact on their classroom practice and teaching methodology. Peacock (2001) thus argued that future teachers should attempt to eliminate any 
detrimental beliefs before they start to teach a foreign language, as if not then many learners could be negatively affected by these ideas. When teachers can identify their detrimental beliefs, then it is easier to reflect on and change at least some of them over a longer period of instruction. Özmen (2012) reported that some of the focal students' beliefs changed during his four-year study, and he ascribed this to the students' engagement in the teaching practicum, which had the greatest impact on the evolution of their beliefs, particularly during the last two years of the study. Similarly, Skela, Sešek and Zavašnik (2008) confirmed in their study that school based teaching practice is of key importance in shaping the future teachers of a foreign language. Grijalva and Barajas's longitudinal research (2013) showed that $40 \%$ of pre-service English language teachers' beliefs changed over the period studied, whereas $60 \%$ remained the same. They assumed that these changes were due to the teaching practice courses, in which students experienced and reflected on teaching. However, some researchers, e.g., Peacock (2001) and Tillema and Knoll (1997), have argued that most of students' beliefs about learning stay unchanged throughout the training. Mattheoudakis (2007) noted that there is not enough information about the content of the programmes presented in the related studies, and that the quality of these programmes may vary significantly.

Teachers' beliefs strongly influence their teaching behaviour, and guide teachers in the adoption of the strategies they apply to cope with the daily challenges of teaching, as well as influencing their teacher consciousness and teaching attitudes, methods and policies (Xu 2012). Teachers should therefore be aware of their own beliefs, explore them and see how they shape their own ways of teaching. The three study groups chosen for the present research are going to work with pre-school and primary school children, when the children are still developing their knowledge of the world, social skills and beliefs about learning, and their teaching will therefore play an influential role in their lives. Furthermore, pre-school and primary school student-teachers might also become future teachers of English to young learners, and in this way influence children's beliefs about foreign language learning in more depth.

\section{The Study}

It has been determined that beliefs about language learning are important for the learning and teaching process, and that learners and teachers may have different attitudes towards learning a new language. Similarly, student-teachers of different subjects may differ in their beliefs about language learning. The main aim of this study was thus to investigate pre-service preschool teachers', primary school teachers', and special education teachers' beliefs about foreign language learning in Slovenia.

\subsection{Research Questions}

The research questions of this study were as follows:

1. What are students' beliefs about foreign language aptitude?

2. Are the beliefs about foreign language aptitude different among students of preschool education, students of primary school education and students of special education?

3. What are students' beliefs about the nature of language learning?

4. Are the beliefs about the nature of language learning different when comparing students of preschool education, students of primary school education, and students of special education? 
5. What are students' beliefs about the motivations and expectations for foreign language learning?

6. Are the beliefs about motivations and expectations for foreign language learning different when observing students of preschool education, students of primary school education, and students of special education?

\subsection{Research Instrument}

A slightly adapted BALLI questionnaire (Beliefs About Language Learning Inventory, Horwitz 1988) was used to collect data in this study. This had a Likert-scale format and learners were asked to choose among strongly agree, agree, neither agree nor disagree, disagree, and strongly disagree options for 32 items. One item (item 4) had the following options: very easy, easy, medium, difficult, very difficult, and there was one question (item 15) with closed response alternatives. The questionnaire was divided into the following five areas: foreign language aptitude ( 9 items), the difficulty of language learning ( 5 items), the nature of language learning (6 items), learning and communication strategies (8 items), and motivation and expectations (6 items).

The questionnaire items were found to be highly reliable (Cronbach's $\alpha=.795$ ).

\subsection{Respondents and Data Collection}

A total of 170 students participated in the study. Since we wanted to investigate whether students' beliefs vary with the programme of study, we included students from Year 1 of preschool education, primary school education, and special education. The students were approximately 19 years old. The study included 57 (33.5\%) students of preschool education, 82 (48.2\%) students of primary school education and $31(18.2 \%)$ students of special education. By the time of the study, they had completed approximately 1,000 hours of first foreign language learning, and many of them about 420 hours of second foreign language learning. The students were all studying at the Faculty of Education, University of Ljubljana, Slovenia in 2017.

\subsection{Data Analysis}

After verifying that the data were free from errors, matrix analyses were conducted using IBM SPSS Statistics software. The data were controlled according to the assumptions of a normal distribution and homogeneity of variance. In view of the research questions, mainly descriptive (absolute frequency, percentage, mean, standard deviation) procedures and statistical tests (oneway analysis of variance, post-hoc comparison - Hochberg's GT2 test and Games-Howell test) were applied. Partial eta-squared was calculated as a measure of effect size.

\section{Results}

The results are presented in five sections according to the main research areas. The sections show the pre-service preschool teachers', primary school teachers', and special education teachers' beliefs about foreign language aptitude (first section), difficulty of language learning (second section), nature of language learning (third section), learning and communication strategies (fourth section), and motivations and expectations (fifth section). 
TABLE 1. Descriptive statistics for foreign language aptitude.

\begin{tabular}{|l|c|c|c|c|c|c|c|c|}
\hline Item description & Subject & $\mathbf{5}^{1}$ & $\mathbf{4}$ & $\mathbf{3}$ & $\mathbf{2}$ & $\mathbf{1}$ & $\mathbf{M}$ & SD \\
\hline 1.2It is easier for children & $\mathrm{A}^{3}$ & 41 & 11 & 3 & 0 & 2 & 4.56 & .887 \\
than adults to learn an & $\mathrm{B}$ & 56 & 20 & 5 & 1 & 0 & 4.60 & .664 \\
FL. & $\mathrm{C}$ & 20 & 9 & 2 & 0 & 0 & 4.58 & .620 \\
\hline 2. Some people have a & $\mathrm{A}$ & 32 & 24 & 0 & 1 & 0 & 4.53 & .601 \\
special ability for learning & $\mathrm{B}$ & 49 & 27 & 5 & 1 & 0 & 4.51 & .671 \\
FLs. & $\mathrm{C}$ & 17 & 12 & 2 & 0 & 0 & 4.48 & .626 \\
\hline 6. People from my & $\mathrm{A}$ & 1 & 19 & 29 & 6 & 2 & 3.19 & .789 \\
country are good at & $\mathrm{B}$ & 5 & 34 & 37 & 6 & 0 & 3.46 & .723 \\
learning FLs. & $\mathrm{C}$ & 3 & 21 & 6 & 1 & 0 & 3.84 & .638 \\
\hline 10. It is easier for & $\mathrm{A}$ & 8 & 15 & 23 & 10 & 1 & 3.33 & .988 \\
someone who already & $\mathrm{B}$ & 5 & 27 & 33 & 13 & 4 & 3.20 & .949 \\
speaks an FL to learn & $\mathrm{C}$ & 2 & 11 & 12 & 6 & 0 & 3.29 & .864 \\
another one. & $\mathrm{A}$ & 3 & 4 & 9 & 19 & 22 & 2.07 & 1.147 \\
\hline 11. People who are good & $\mathrm{B}$ & 3 & 8 & 14 & 24 & 33 & 2.07 & 1.142 \\
at maths or science are & $\mathrm{C}$ & 0 & 1 & 5 & 15 & 10 & 1.90 & .790 \\
not good at learning FLs. & $\mathrm{A}$ & 3 & 10 & 17 & 18 & 9 & 2.65 & 1.110 \\
\hline 16. I have a special ability & $\mathrm{B}$ & 1 & 9 & 33 & 26 & 13 & 2.50 & .933 \\
for learning FLs. & $\mathrm{C}$ & 0 & 5 & 13 & 12 & 1 & 2.71 & .783 \\
\hline & $\mathrm{A}$ & 0 & 0 & 19 & 12 & 26 & 1.88 & .888 \\
\hline 19. Women are better & $\mathrm{B}$ & 0 & 3 & 13 & 27 & 39 & 1.76 & .854 \\
than men at learning & $\mathrm{C}$ & 0 & 1 & 7 & 9 & 14 & 1.84 & .898 \\
languages. & $\mathrm{A}$ & 3 & 26 & 18 & 8 & 2 & 3.35 & .916 \\
\hline 31. People who speak & $\mathrm{B}$ & 7 & 29 & 37 & 6 & 3 & 3.38 & .884 \\
more than one language & $\mathrm{C}$ & 0 & 12 & 14 & 5 & 0 & 3.23 & .717 \\
are very intelligent. & $\mathrm{A}$ & 23 & 19 & 12 & 3 & 0 & 4.09 & .912 \\
\hline 34. Everyone can learn to & $\mathrm{B}$ & 39 & 25 & 9 & 8 & 1 & 4.13 & 1.039 \\
speak an FL. & $\mathrm{C}$ & 8 & 16 & 7 & 0 & 0 & 4.03 & .706 \\
\hline
\end{tabular}

Table 1 presents the pre-service preschool teachers', primary school teachers' and special education teachers' beliefs about FL aptitude. The highest level of agreement is demonstrated with regard to the first item, with $68.82 \%$ of all respondents completely agreeing with the first statement on the relative ease of FL learning in childhood $(M=4.58)$. Further analysis showed that there is a statistically significant difference in the beliefs of students with regard to item 6 , $F(2,176)=7.888, p=.001, \eta^{2}=.086$ for Group A, Group B, and Group C, respectively. The effect size is medium. Post-hoc analyses using Hochberg's GT2 test indicated that students in Group C $(M=3.84, S D=.64)$ agreed with the item more than those in Group B $(M=3.46$, $S D=.72)(p=.047)$ or Group A $(M=3.19, S D=.79)(p<.001)$, with these latter two groups not differing significantly in this regard $(p=.097)$.

5 = strongly agree, 4 = agree, 3 = neither agree nor disagree, 2 = disagree, 1 = strongly disagree

The items are numbered in the same manner as in the Horwitz BALLI questionnaire (1988)

$\mathrm{A}=$ students of preschool education, $\mathrm{B}=$ students of primary teacher education, $\mathrm{C}=$ students of special education 
Similarly, more than one half of the respondents $(57.64 \%)$ completely agreed with the second item, that some people have a special ability for learning FLs, and none of them $(0.0 \%)$ completely disagreed with this statement. More than half of the respondents (56.07\%) neither agreed nor disagreed regarding whether it is easier for someone who already speaks an FL to learn another one $(M=3.28)$.

A total of $38.23 \%$ of all respondents completely disagreed with the statement that people who are good at maths or science are not good at learning FLs (item No. 11), with 34.11\% disagreeing with the item $(M=2.04)$.

The item about having a special ability for learning FLs gained a very low level of agreement (item No. 16), with $0.002 \%$ of all respondents completely agreeing with the statement and $0.02 \%$ agreeing, whereas the item that claimed women are better than men at learning languages (item No. 19) gained the lowest level of agreement, with none of the respondents $(0.0 \%)$ completely agreeing with the item and almost half $(46.47 \%)$ completely disagreeing with it $(M=1.81)$. A total of $40.58 \%$ of all the respondents neither agreed nor disagreed with the statement that people who speak more than one language are very intelligent (item No. 31), while only $2.94 \%$ of all respondents completely disagreed with this. Moreover, none of the students of special education disagreed with this item. Regarding the idea that everyone can learn to speak an FL (item No. 34); $41.17 \%$ of all respondents completely agreed, and only one person (0.58\%) completely disagreed with this claim.

TABLE 2. Descriptive statistics for difficulty of language learning.

\begin{tabular}{|c|c|c|c|c|c|c|c|c|}
\hline Item description & Subject & 5 & 4 & 3 & 2 & 1 & $\mathbf{M}$ & SD \\
\hline \multirow{3}{*}{$\begin{array}{l}\text { 3. Some languages are easier } \\
\text { than others. }\end{array}$} & A & 34 & 22 & 1 & 0 & 0 & 4.58 & .533 \\
\hline & B & 42 & 32 & 7 & 0 & 1 & 4.39 & .750 \\
\hline & $\mathrm{C}$ & 21 & 7 & 3 & 0 & 0 & 4.58 & .672 \\
\hline \multirow[t]{3}{*}{ 4. The English language is ${ }^{4}$} & $\mathrm{~A}$ & 1 & 12 & 31 & 12 & 1 & 3.00 & .756 \\
\hline & B & 3 & 16 & 51 & 9 & 3 & 3.09 & .773 \\
\hline & C & 0 & 10 & 16 & 5 & 0 & 3.16 & .688. \\
\hline \multirow{3}{*}{$\begin{array}{l}\text { 15. If someone spent one } \\
\text { hour a day learning a } \\
\text { language, how long would } \\
\text { it take them to speak the } \\
\text { language very well?? }\end{array}$} & A & 6 & 31 & 17 & 1 & 2 & 3.67 & .831 \\
\hline & B & 11 & 32 & 27 & 9 & 3 & 3.48 & .984 \\
\hline & $\mathrm{C}$ & 5 & 17 & 8 & 1 & 0 & 3.84 & .735 \\
\hline \multirow{3}{*}{$\begin{array}{l}\text { 26. It is easier to speak } \\
\text { than understand a foreign } \\
\text { language. }\end{array}$} & A & 1 & 3 & 9 & 29 & 15 & 2.05 & .895 \\
\hline & B & 0 & 5 & 11 & 34 & 32 & 1.87 & .872 \\
\hline & C & 1 & 2 & 6 & 18 & 4 & 2.29 & 902 \\
\hline \multirow{3}{*}{$\begin{array}{l}\text { 35. It is easier to read and } \\
\text { write English than to speak } \\
\text { and understand it. }\end{array}$} & A & 4 & 8 & 17 & 19 & 9 & 2.63 & 1.128 \\
\hline & B & 6 & 10 & 23 & 29 & 14 & 2.57 & 1.133 \\
\hline & C & 0 & 3 & 15 & 11 & 2 & 2.61 & .761 \\
\hline
\end{tabular}

For item 4: 5 = very easy, 4 = easy, $3=$ medium, $2=$ difficult, $1=$ very difficult

For item 15:5 = less than a year, $4=$ between 1 and 2 years, $3=$ between 2 and 5 years, $4=$ between 5 and 10 years, $5=$ you cannot learn a language with one hour a day 
Table 2 presents the pre-service preschool teachers', primary school teachers' and special education teachers' beliefs about the difficulty of language learning.

More than half of all the respondents (57.06\%) completely agreed with the statement that some languages are easier than others (item No. 3). Similarly, more than half $(57.64 \%)$ stated that the English language is neither easy nor difficult to learn (item No .4); 47.05\% agreed that if someone spent one hour a day learning a language, then it would take her/him between one and two years to speak the language very well (item No. 15); 47.64\% of all respondents disagreed that it is easier to speak than understand a foreign language (item No. 26). Only 5.88\% of all respondents completely disagreed that it is easier to read and write English than to speak and understand it (item No. 35). The highest level of agreement was for the third item $(M=4.49, S$ $=.67)$, while item No. 26 gained the lowest level of agreement $(M=2.01, S=.89)$.

TABLE 3. Descriptive statistics for the nature of language learning.

\begin{tabular}{|c|c|c|c|c|c|c|c|c|}
\hline Item description & Subject & 5 & 4 & 3 & 2 & 1 & $\mathbf{M}$ & SD \\
\hline \multirow{3}{*}{$\begin{array}{l}\text { 8. It is necessary to learn } \\
\text { about English-speaking } \\
\text { cultures to speak English. }\end{array}$} & A & 1 & 13 & 25 & 13 & 5 & 2.86 & .934 \\
\hline & B & 6 & 16 & 27 & 29 & 4 & 2.89 & 1.018 \\
\hline & $\mathrm{C}$ & 1 & 4 & 16 & 6 & 4 & 2.74 & .965 \\
\hline \multirow{3}{*}{$\begin{array}{l}\text { 12. It is best to learn } \\
\text { English in an English- } \\
\text { speaking country. }\end{array}$} & A & 28 & 18 & 8 & 1 & 2 & 4.21 & .995 \\
\hline & $\mathrm{B}$ & 44 & 26 & 12 & 0 & 0 & 4.39 & .733 \\
\hline & $\mathrm{C}$ & 12 & 15 & 2 & 2 & 0 & 4.19 & .833 \\
\hline \multirow{3}{*}{$\begin{array}{l}\text { 17. The most important } \\
\text { part of learning a foreign } \\
\text { language is learning new } \\
\text { words. }\end{array}$} & A & 8 & 23 & 21 & 5 & 0 & 3.60 & .842 \\
\hline & $\mathrm{B}$ & 11 & 29 & 29 & 10 & 3 & 3.43 & .994 \\
\hline & C & 0 & 13 & 16 & 1 & 1 & 3.32 & .702 \\
\hline \multirow{3}{*}{$\begin{array}{l}\text { 24. The most important } \\
\text { part of learning a foreign } \\
\text { language is learning } \\
\text { grammar. }\end{array}$} & A & 5 & 17 & 19 & 14 & 2 & 3.16 & 1.014 \\
\hline & $\mathrm{B}$ & 1 & 21 & 32 & 22 & 6 & 2.87 & .926 \\
\hline & $\mathrm{C}$ & 0 & 6 & 16 & 7 & 2 & 2.84 & .820 \\
\hline \multirow{3}{*}{$\begin{array}{l}\text { 28. Learning a foreign } \\
\text { language is different than } \\
\text { learning other academic } \\
\text { subjects. }\end{array}$} & A & 11 & 24 & 18 & 4 & 0 & 3.74 & .856 \\
\hline & B & 31 & 42 & 9 & 0 & 0 & 4.27 & .649 \\
\hline & $\mathrm{C}$ & 8 & 20 & 3 & 0 & 0 & 4.16 & .583 \\
\hline \multirow{3}{*}{$\begin{array}{l}\text { 29. The most important } \\
\text { part of learning English is } \\
\text { learning how to translate } \\
\text { from my own language. }\end{array}$} & A & 7 & 14 & 29 & 4 & 3 & 3.32 & .967 \\
\hline & B & 7 & 10 & 39 & 21 & 5 & 2.91 & .984 \\
\hline & $\mathrm{C}$ & 0 & 4 & 14 & 12 & 1 & 2.68 & .748 \\
\hline
\end{tabular}

Table 3 presents the pre-service preschool teachers', primary school teachers' and special education teachers' beliefs about the nature of language learning. The highest level of agreement is demonstrated with regard to item No. $24(M=4.29, S D=.94)$, while item No. 8 gained the lowest level of agreement $(M=2.85, S D=.98)$. Only $4.70 \%$ of all respondents completely agreed that it is necessary to learn about English-speaking cultures to speak English (item No. 8), whereas almost half (49.41\%) completely agreed that it is best to learn English in an Englishspeaking country (item No. 12); 38.82\% of all respondents could not decide whether the most important part of learning a foreign language is learning new words (item No. 17); similarly, 
$39.41 \%$ of all respondents could not decide whether the most important part of learning a foreign language is learning grammar (item No. 24).

Half of the respondents (50.58\%) agreed that learning a foreign language is different than learning other academic subjects (item No. 28). Further analysis showed that there is a statistically significant difference in the beliefs of students for item No. 28, with $F(2,176)=9.597$, $p=.000, \eta^{2}=.103$ for Group A, Group B, and Group C, respectively, and the effect size is medium. Post-hoc analyses using the Games-Howell test indicated that students in Group C $(M=4.16, S D=.58)$ agreed with the item to a greater degree of statistical significance $(p=.020)$ than the students in Group A $(M=3.74, S D=.85)$. Statistical significance $(p<.001)$ was also found in the responses to this item for Group A $(M=3.74, S D=.85)$ and Group B $(M=4.27$, $S D=.64)$, while the students in Group B and Group C did not differ significantly in this regard $(p=.678)$.

Almost half of the respondents could not decide whether the most important part of learning English is learning how to translate from their own language (item No. 29). Further analysis showed that there is a statistically significant difference in the beliefs of students for item No. 29, with $F(2,176)=5.379, p=.005, \eta^{2}=.061$ for Group A, Group B, and Group C, respectively. The effect size is medium. Post-hoc analyses using the Games-Howell test indicated that the students in Group C $(M=2.68, S D=.75)$ agreed with the item $(p=.008)$ more than those in Group A $(M=3.32, S D=.97)$. Statistical significance $(p<.042)$ was also found in the responses to this item for Group A $(M=3.32, S D=.97)$ and Group B $(M=2.91, S D=.98)$. However, the students in Group B and Group C did not differ significantly in this regard $(p=.547)$.

TABLE 4. Descriptive statistics for learning and communication strategies.

\begin{tabular}{|l|c|c|c|c|c|c|c|c|}
\hline Item description & Subject & $\mathbf{5}$ & $\mathbf{4}$ & $\mathbf{3}$ & $\mathbf{2}$ & $\mathbf{1}$ & $\mathbf{M}$ & SD \\
\hline 7. It is important to speak & $\mathrm{A}$ & 9 & 23 & 19 & 6 & 0 & 3.61 & .881 \\
English with excellent & $\mathrm{B}$ & 20 & 35 & 17 & 9 & 1 & 3.78 & .982 \\
pronunciation. & $\mathrm{C}$ & 3 & 19 & 7 & 2 & 0 & 3.74 & .729 \\
\hline 9. You should not say & $\mathrm{A}$ & 0 & 2 & 8 & 25 & 22 & 1.82 & .805 \\
anything in English until & $\mathrm{B}$ & 1 & 2 & 2 & 27 & 50 & 1.50 & .774 \\
you can say it correctly. & $\mathrm{C}$ & 0 & 0 & 2 & 12 & 17 & 1.52 & .626 \\
\hline 13. I enjoy practicing & $\mathrm{A}$ & 14 & 14 & 15 & 11 & 3 & 3.44 & 1.210 \\
English with the native & $\mathrm{B}$ & 24 & 25 & 22 & 9 & 2 & 3.73 & 1.078 \\
English speakers I meet. & $\mathrm{C}$ & 8 & 12 & 9 & 2 & 0 & 3.84 & .898 \\
\hline 14. It is OK to guess if & $\mathrm{A}$ & 3 & 14 & 27 & 12 & 1 & 3.11 & .859 \\
you don't know a word in & $\mathrm{B}$ & 7 & 20 & 38 & 12 & 5 & 3.15 & .983 \\
English. & $\mathrm{C}$ & 6 & 5 & 16 & 4 & 0 & 3.42 & .958 \\
\hline 18. It is important to & $\mathrm{A}$ & 33 & 17 & 6 & 1 & 0 & 4.44 & .756 \\
repeat and practice a lot. & $\mathrm{B}$ & 46 & 29 & 6 & 1 & 0 & 4.46 & .688 \\
& $\mathrm{C}$ & 10 & 18 & 3 & 0 & 0 & 4.23 & .617 \\
\hline 21. I feel shy when & $\mathrm{A}$ & 1 & 20 & 8 & 15 & 13 & 2.67 & 1.230 \\
speaking English with & $\mathrm{B}$ & 8 & 18 & 18 & 26 & 12 & 2.80 & 1.222 \\
other people. & $\mathrm{C}$ & 4 & 5 & 7 & 11 & 4 & 2.81 & 1.250 \\
\hline
\end{tabular}




\begin{tabular}{|l|c|c|c|c|c|c|c|c|}
\hline $\begin{array}{l}\text { 23. If beginning students } \\
\text { are allowed to make } \\
\text { mistakes in English, it will }\end{array}$ & $\mathrm{A}$ & 4 & 15 & 18 & 15 & 5 & 2.96 & 1.085 \\
be difficult for them to & $\mathrm{B}$ & 4 & 8 & 23 & 28 & 19 & 2.39 & 1.097 \\
speak correctly later on. & $\mathrm{C}$ & 1 & 5 & 7 & 13 & 5 & 2.48 & 1.061 \\
\hline 27. It is important to & $\mathrm{A}$ & 14 & 25 & 14 & 4 & 0 & 3.86 & .875 \\
practice with tapes or & $\mathrm{B}$ & 29 & 41 & 11 & 1 & 0 & 4.20 & .710 \\
CDs. & $\mathrm{C}$ & 3 & 21 & 6 & 1 & 0 & 3.84 & .638 \\
\hline
\end{tabular}

Table 4 presents the pre-service preschool teachers', primary school teachers' and special education teachers' beliefs about learning and communication strategies. The highest level of agreement was demonstrated with regard to item No. $18(M=4.41, S D=.70)$, while item No. 9 gained the lowest level of agreement $(M=1.61, S D=.77)$.

Only one of the respondents $(0.58 \%)$ completely disagreed with the statement that it is important to speak English with excellent pronunciation (item No. 7), whereas more than half $(52.35 \%)$ completely disagreed that you should not say anything in English until you can say it correctly (item No. 9). Further analysis showed that there is a statistically significant difference in the beliefs of the students in Group A, Group B, and Group C regarding item No. 9, F $(2,176)$ $=3.365, p=.037, \eta^{2}=.039$. The effect size is small. Post-hoc analyses using the Hochberg's GT2 test indicated that students in Group C $(M=1.52, S D=.63)$ and Group A $(M=1.82, S D=.81)$ $(p=.197)$ did not differ significantly in agreeing with item No. 9, while statistical significance $(p=.042)$ was found between the responses of the students in Group B $(M=1.50, S D=.77)$ and Group A $(M=1.82, S D=.81)$.

A total of $2.94 \%$ of all respondents completely disagreed with item No. 13 (I enjoy practicing English with the native English speakers I meet.); similarly, 3.52\% of all respondents completely disagreed with item No. 14 (It is OK to guess if you don't know a word in English.); however, almost half (47.64\%) of the respondents could decide regarding this item. In contrast, more than half the respondents $(52.35 \%)$ completely agreed that it is important to repeat and practice a lot (item No. 18). Only 7.64\% of the respondents completely agreed with item No. 21 (I feel shy speaking English with other people); similarly, only $5.29 \%$ of completely agreed with item No. 23 (If beginning students are allowed to make mistakes in English, it will be difficult for them to speak correctly later on.). None of the respondents (0.0\%) disagreed that it is important to practice with tapes or CDs (item No. 27). Further analysis showed that there is a statistically significant difference in the beliefs of the students in Group A, Group B, and Group C regarding item No. 27, $F(2,176)=4.350, p=.014, \eta^{2}=.050$. The effect size is small. Post-hoc analyses using the Hochberg's GT2 test indicated that the students in Group A $(M=2.96, S D=.81)$ agreed with the item $(p=0.033)$ more than those in Group B $(M=2.39, S D=1.09)$. The students in Group C and Group B did not differ significantly $(p=.079)$ in this regard, nor did those in Group C and Group A $(p=.999)$.

Table 5 presents the pre-service preschool teachers', primary school teachers' and special education teachers' beliefs about motivations and expectations. The highest level of agreement is demonstrated with regard to item No. $32(M=4.62, S D=.63)$, while item No. 25 gained the lowest level of agreement $(M=3.56, S D=1.02)$. 
TABLE 5. Descriptive statistics for motivations and expectations.

\begin{tabular}{|l|c|c|c|c|c|c|c|c|}
\hline Item description & Subject & $\mathbf{5}$ & $\mathbf{4}$ & $\mathbf{3}$ & $\mathbf{2}$ & $\mathbf{1}$ & $\mathbf{M}$ & SD \\
\hline 5. I believe I will learn to & $\mathrm{A}$ & 10 & 25 & 16 & 4 & 2 & 3.65 & .973 \\
speak English very well. & $\mathrm{B}$ & 11 & 47 & 22 & 2 & 0 & 3.82 & .687 \\
& $\mathrm{C}$ & 3 & 14 & 12 & 2 & 0 & 3.58 & .765 \\
\hline 20. People in my country & $\mathrm{A}$ & 14 & 22 & 16 & 2 & 3 & 3.74 & 1.044 \\
feel it is important to & $\mathrm{B}$ & 25 & 35 & 17 & 5 & 0 & 3.98 & .875 \\
speak English. & $\mathrm{C}$ & 10 & 17 & 3 & 1 & 0 & 4.16 & .735 \\
\hline 25. I would like to learn & $\mathrm{A}$ & 12 & 19 & 18 & 6 & 2 & 3.58 & 1.051 \\
English so that I can get & $\mathrm{B}$ & 16 & 28 & 24 & 14 & 0 & 3.56 & .995 \\
to know native English & $\mathrm{C}$ & 5 & 14 & 7 & 3 & 2 & 3.55 & 1.091 \\
speakers better. & $\mathrm{A}$ & 33 & 19 & 3 & 2 & 0 & 4.46 & .758 \\
\hline 30. If I learn to speak & $\mathrm{B}$ & 58 & 21 & 2 & 1 & 0 & 4.66 & .593 \\
English very well, I & $\mathrm{C}$ & 13 & 12 & 5 & 1 & 0 & 4.19 & .833 \\
will have better job & $\mathrm{A}$ & 35 & 15 & 7 & 0 & 0 & 4.49 & .710 \\
opportunities. & $\mathrm{B}$ & 60 & 18 & 4 & 0 & 0 & 4.68 & .564 \\
\hline 32. I want to learn to & $\mathrm{C}$ & 24 & 4 & 3 & 0 & 0 & 4.68 & .653 \\
speak English very well. & $\mathrm{A}$ & 33 & 11 & 9 & 4 & 0 & 4.28 & .978 \\
& $\mathrm{~B}$ & 33 & 27 & 18 & 4 & 0 & 4.09 & .905 \\
& $\mathrm{C}$ & 13 & 12 & 3 & 3 & 0 & 4.13 & .957 \\
\hline 33. I would like to have & &
\end{tabular}

A total of $51.76 \%$ of all respondents agrees with item No. 5 (I believe I will learn to speak English very well.) Only $1.76 \%$ of all respondents completely disagree with item No. 20 (People in my country feel it is important to speak English.); similarly, only $2.35 \%$ of all respondents completely disagree with item No. 25 (I would like to learn English so that I can get to know native English speakers better.). None of the respondents $(0.0 \%)$ completely disagrees that if she/he learns to speak English very well, she/he will have better job opportunities (item No. 30); $85 \%$ of all respondents completely agree that they want to speak English very well (item No. 32 ). None of the respondents $(0.0 \%)$ completely disagree with item No. 33 (I would like to have English-speaking friends.).

Further analysis showed that there is a statistically significant difference in the beliefs of students with regard to item No. 30, $F(2,176)=5.206, p=.006, \eta^{2}=.059$ for Group A, Group B, and Group C. The effect size is small. Post-hoc analyses using the Hochberg's GT2 test indicated that the students in Group C $(M=4.19, S D=0.83)$ agreed with the item $(p=.018)$ more than those in Group B $(M=4.66, S D=0.59)$. The students in Group A and Group C $(\mathrm{p}=.319)$, and Group B and Group C $(p=.214)$, did not differ significantly with regard to this item.

\section{Discussion}

The present research demonstrates that Slovenian students of preschool education, students of primary school education, and students of special education mostly do not differ in their beliefs about FL aptitude. This can be attributed to their comparable cultural, social and school 
backgrounds. A total of $68.82 \%$ of all the students completely agreed that it is easier for children than adults to learn an FL. Post-hoc analysis using the Hochberg's GT2 test indicated that special education students $(M=3.84, S D=.64)$ agreed with the item more than primary education $(M=3.46, S D=.72)(p=.047)$ and preschool education students $(M=3.19, S D=.79)$ $(p<.001)$ do, with the latter two groups not differing significantly on this item $(p=.097)$. Comparing the beliefs of the Slovenian students to those of students from other cultures, some significant differences can be observed. For example, $44 \%$ of the Slovenian students who took part in the survey strongly agreed or agreed that people who speak more than one language are very intelligent, compared to 76\% of Iranian students (Sadeghi and Abdi 2015) and 64\% of first-year students from Hong Kong (Peacock 2001). Interestingly, only $18 \%$ of experienced teachers in Peacock's study (ibid.) had the same belief. These results might be of concern, as the student-teachers may blame a lack of intelligence for poor success in their learners when starting classroom work in a few years' time.

Regarding the nature of learning, $49 \%$ of the students in the present study strongly agreed or agreed that learning new words is the most important part of language learning, whereas as many as $82 \%$ of the Iranian students thought so (Sadeghi and Abdi 2015). Similarly, only $29 \%$ of this study's Slovenian students strongly agreed or agreed with the statement that grammar is the most important part of language learning, whereas 60\% of Iranian students (Sadeghi and Abdi 2015) and $52 \%$ of Hong Kong students believed so (Peacock 2001). The reason for this might be found in the traditionally grammar-focused ways of teaching that Asian students are still exposed to, whereas in Slovenian schools the prevailing approach to teaching an FL is the communicative one. If the student-teachers believe grammar is the most crucial part of learning, they may overemphasise its role in their future teaching.

As far as learning and communicative strategies are concerned, 64\% of the Slovenian students strongly agreed or agreed that it is important to speak English with excellent pronunciation, compared to $90 \%$ of the Iranian students and $40 \%$ of the students from Hong Kong in Peacock (2001). These results might be connected to the different educational and FL contexts in the three countries. Nowadays, when there are so many varieties of international English, it is difficult to identify what "excellent" means in this context, although the key ingredient of a good pronunciation model should be intelligibility, especially since learners are more likely to communicate with other non-native speakers than with native speakers of English (see also Jenkins 2002).

Half of the respondents (50.58\%) agreed that learning a foreign language is different than learning other academic subjects (item No. 28). Post-hoc analyses using the Games-Howell test indicated that special education students $(M=4.16, S D=.58)$ had greater agreement with this item $(p=.020)$ than the preschool education students $(M=3.74, S D=.85)$. Statistical significance $(p<.001)$ is also found between the responses of the preschool students $(M=3.74, S D=.85)$ and primary education students $(M=4.27, S D=.64)$. Moreover, the primary education students and special education students did not differ significantly in this regard $(p=.678)$. Looking at other cultures, as many as $71 \%$ of the students from Hong Kong agreed with this item (Peacock 2001). Scholars have argued that $L 2$ learning differs from learning other school subjects, because it is more "socially and culturally bound" (Dörnyei 2003, 4). Furthermore, you can learn a language across different dimensions and you can adapt it according to your own needs. The knowledge elements of a language are interconnected, and the knowledge one gains is broadened rather than built upon. However, there are certain elements of language learning that are very similar to learning other academic subjects. 
More than half the respondents (52.35\%) completely disagreed with item No. 9, stating that you should not say anything in English until you can say it correctly, in comparison with 73\% of Iranian learners who strongly agreed or agreed with this statement (Sadeghi and Abdi 2015). Again, this can be attributed to the different ways of teaching the learners in these two countries have been exposed to. Statistical significance $(p=.042)$ is found between the responses from the between primary education students $(M=1.50, S D=.77)$ and preschool education students $(M=1.82, S D=.81)$ for this item.

Regarding students' beliefs about motivations and expectations, 91\% of all the respondents completely agreed or agreed with the item stating that if they learn to speak English very well, they will have better job opportunities. Post-hoc analyses using the Hochberg's GT2 test indicated that special education students $(M=4.19, S D=0.83)$ agreed with the item $(p=.018)$ more than the primary education students $(M=4.66, S D=0.59)$. The result is interesting, since primary school teachers are the ones who will most likely teach English, while the special education students will most likely not have to do this. If the primary school students decide to study English as well as other subjects (which they have an opportunity to do), their chances of getting a job at primary school are much higher. The results here can also be compared to those of other studies, e.g., 90\% of the Iranian students believed that speaking English fluently will bring them better job opportunities (Sadeghi and Abdi 2015), and 90\% of those from Hong Kong felt the same (Peacock 2001). Interestingly, regardless of their cultural backgrounds, the students in all three studies seem to agree that knowledge of English will help them in their careers.

\section{Conclusion}

The present study attempted to identify the language-learning beliefs of Slovenian studentteachers, with those from three different study programmes being surveyed: preschool students, primary education students, and special education students. The results were presented in three sections according to the main research areas: language-learning aptitude, nature of language learning, and students' motivations and expectations for language learning. Despite their different study programmes, the students did not differ significantly in their beliefs. This might stem from their similar cultural backgrounds and the corresponding teaching approaches of their primary and secondary foreign language educations, especially since the comparison that was made with students from other cultural backgrounds showed some differences in their beliefs. Since the students examined in the current work had only just started their studies, their beliefs might change over the course of these, as has been shown in previous research (e.g., Özmen 2012; Grijalva and Barajas 2013), most likely through their teaching practice, school observations and self-reflection. It would also be worthwhile to compare their responses to those of experienced teachers. Moreover, the results of the present study might help language teachers to overcome some of the learners' negative beliefs that have been highlighted in this work's results, and to discuss the nature of foreign language learning more regularly and effectively with their learners. This is imperative, because the student-teachers included in the present study will be working with children, when they are still developing their self-esteem, learning strategies and beliefs about learning, and thus these future teachers will play a significant role in the children's development. Furthermore, pre-school and primary school student-teachers have the possibility of becoming teachers of English to young learners, and will thus influence the children's beliefs about foreign language learning through their own teaching attitudes and selections of FL teaching methods. 


\section{References}

Cochran, Jeff L., R. Steve McCallum, and Sherry Mee Bell. 2010. “Three A's: How do Attributions, Attitudes and Aptitude Contribute to Foreign Language Learning." Foreign Language Annals 43 (4): 566-82. http:// dx.doi.org/10.1111/j.1944-9720.2010.01102.x.

Dörnyei, Zoltán. 2003. "Attitudes, Orientations, and Motivations in Language Learning: Advances in Theory, Research, and Applications.” Language Learning 53 (1): 3-32. http://dx.doi.org/10.1111/14679922.53222 .

Gardner, Robert C. 1985. Social Psychology and Second Language Learning: The Role of Attitudes and Motivation. London: Edward Arnold Publishers.

Grijalva, Sofia D. Cota, and Elizabeth Ruiz-Esparza Bajaras. 2013. "Pre-Service Teachers' Beliefs about Language Teaching and Learning: A Longitudinal Study." Profile 15 (1): 81-95. https://revistas.unal.edu. co/index.php/profile/article/view/37866/40577.

Horwitz, Elaine K. 1988. "The Beliefs about Language Learning of Beginning University Foreign Language Students.” Modern Language Journal 72 (3): 283-94. http://dx.doi.org/10.1111/j.1540-4781.1988. tb04190.x.

Jenkins, Jennifer. 2002. "A Sociolinguistically Based, Empirically Researched Pronunciation Syllabus for English as an International Language." Applied Linguistics 23 (1): 83-103. http://dx.doi.org/10.1093/ applin/23.1.83.

Kuntz, Patricia S. 1996. "Beliefs about Language Learning: The Horwitz model." (ERIC Document Reproduction Service, No. ED397649). Accessed August 28, 2017. http://files.eric.ed.gov/fulltext/ ED397649.pdf.

Mattheoudakis, Marina. 2007. "Tracking Changes in Pre-Service EFL Teacher Beliefs in Greece: A Longitudinal Study." Teaching and Teacher Education 23 (8): 1272-88. http://dx.doi.org/10.1016/j. tate.2006.06.001.

Nikitina, Larisa, and Fumitaka Furuoka. 2006. "Re-Examining Horwitz’s Beliefs about Language Learning Inventory (BALLI) in the Malaysian Context." Electronic Journal of Foreign Language Teaching 3 (2): 209-19.

Özmen, Kemal Sinan. 2012. "Exploring Student Teachers' Beliefs about Language Learning and Teaching: A Longitudinal Study." Current Issues in Education 15 (1): 1-16.

Peacock, Mattthew. 2001. "Pre-Service ESL Teachers' Beliefs about Second Language Learning: A Longitudinal Study.” System 29 (2): 177-95. http://dx.doi.org/10.1016/S0346-251X(01)00010-0.

Richards, Jack C., and Charles Lockhart. 1994. Reflective Teaching in Second Language Classrooms. Cambridge: Cambridge University Press.

Richardson, Virginia. 1996. "The Role of Attitudes and Beliefs in Learning to Teach." In Handbook of Research on Teacher Education (2nd ed.), edited by John Sikula, 102-19. New York: Macmillan.

Sadeghi, Karim, and Heidar Abdi. 2015. "A Comparison of EFL Teachers and Students' Beliefs about Language Learning.” MEXTESOL Journal 39 (1): 1-14.

Skela, Janez, Urška Sešek, and Mihaela Zavašnik. 2008. "An Evaluation of the School-Based Teaching Practice in the Training of EFL Teachers by the English Department of the Faculty of Arts in Ljubljana." ELOPE 5 (1-2): 185-97. http://dx.doi.org/10.4312/elope.5.1-2.185-198.

Tillema, Harm H., and Wout E. Knoll. 1997. "Promoting Student Teacher Learning through Conceptual Change or Direct Instruction.” Teaching and Teacher Education 13 (6): 579-95. http://dx.doi. org/10.1016/S0742-051X(97)80002-9. 
Truitt, Susan. 1995. "Beliefs about Language Learning: A Study of Korean University Students Learning English." Texas Papers in Foreign Language Education 2 (1): 1-14.

Vaid, Jyotsna, and Rachel Hull. 2002. "Re-Envisioning the Bilingual Brain Using Functional Neuroimaging: Methodological and Interpretive Issues." In Advances in the Neurolinguistic Study of Bilingualism, edited by Franco Fabbro, 315-55. Udine: Forum.

Wesely, Pamela M. 2012. "Learner Attitudes, Perceptions and Beliefs in Language Learning." Foreign Language Annals 45 (1): 98-117. http://dx.doi.org/ 10.1111/j.1944-9720.2012.01181.x.

Xu, Li. 2012. "The Role of Teachers' Beliefs in the Language Teaching-Learning Process." Theory and Practice in Language Studies 2 (7): 1397-1402. http://dx.doi.org/10.4304/tpls.2.7.1397-1402.

Yavuz, Fatih. 2015. "Pre-Service Teachers' Attitudes to Foreign Language Teaching; Change or Status Quo?” Procedia - Social and Behavioral Sciences 191: 1823-27. http://dx.doi.org/10.1016/j.sbspro.2015.04.226. 